\title{
Catalysts for Students' Learning in New Normal: Science Educator's Point of View
}

\author{
Marjorie Bait-it Reponte, Jewish Araneta Merin \\ College of Teacher Education, Cebu Normal University, Cebu, Philippines \\ Email address: \\ marjorie.reponte511@gmail.com (M. Bait-it R.), jewishmerin@gmail.com (J. A. Merin)
}

\section{To cite this article:}

Marjorie Bait-it Reponte, Jewish Araneta Merin. Catalysts for Students' Learning in New Normal: Science Educator's Point of View. International Journal of Elementary Education. Vol. 10, No. 3, 2021, pp. 56-60. doi: 10.11648/j.ijeedu.20211003.12

Received: May 29, 2021; Accepted: July 2, 2021; Published: August 24, 2021

\begin{abstract}
SARS-CoV-2 is a virus that affects not only the cells of a living organism but greatly the "biome." One aspect of society that we can easily recognize which made a great leap is the Education Sector. Face to Face learning is discouraged to mitigate the COVID-19 cases hence, Remote Learning is the highlight of the "New Normal" Education. With this, there are identified modalities of learning options to choose aside from the traditional mode of conducting classes in the classroom namely Remote - Print Learning which uses printed modules as the main tool to deliver instruction, Remote - Online (Asynchronous) which uses digital materials for instruction purposes and Remote - Online (Synchronous) which optimizes internet connectivity and online tools to deliver instruction. In this study, it aspires to examine and decipher the preparations as well as the challenges encountered by the eight (8) Science educators across different areas of Cebu, Philippines in teaching the curriculum and in conducting assessment in New Normal classes to Junior High School Students. Data collection is made possible via Google Form in respect to the imposed government protocols. In addition, it shows that both private and public academic institutions exhibit dominantly the flexible, remote learning modality which is Modular Distance Learning where assessment tools serve as catalysts in students' learning for it is the main line of communication to their students. This study highly suggests that curriculum stakeholders, especially educators must conduct seminars-workshops in crafting appropriate assessment tools and applying strategies in teaching and conducting assessments in different learning modalities that will provide quality education to diverse learners with different resources.
\end{abstract}

Keywords: Science Educators, New Normal, Remote Learning, Assessment Tools, Students’ Learning

\section{Introduction}

SARS-CoV-2 is a virus that affects not only the cells of a living organism but greatly the "biome." In different means and amounts, the biome's, society, and different aspects have been altered to attain the state of equilibrium. One aspect of society that we can easily recognize which made a great leap is the Education Sector. The government disallowed Face-toFace Learning to follow mandated health protocols and mitigate the active cases of Covid-19 but emphasized the key role of Distance Learning Modalities in New Normal Education to continue the goal of all academic institutions which is to provide quality education.

A quality education is all about catering the needs and developing each child holistically regardless of his personal background [1]. With this goal, curriculum stakeholders, specifically educators, must strengthen their relationships or interactions with their colleagues and also with their students and improve their knowledge, instruction, methodologies, and strategies. A quality education will be ensured through providing quality assessments grounded with Constructivist Learning Theory which refers to the concept that in order to learn and to construct their own meaning, learners should work both on their own and together with the class [2].

In the New Normal, Science Educators like other educators make a great effort in choosing and designing their assessment since "assessment has been described as the heart of the student experience and is probably the single biggest influence on how students approach their learning [3]." In other words, assessment will serve as catalysts for students to learn and perform well even if there is no physical contact with the teachers and classmates. 


\subsection{Theoretical Background}

"Tell me and I forget. Teach me and I remember. Involve me and I will learn." This is a very common quote that can be related to education and learning but a very good reminder to teachers. The greatest factor of teaching is the learners especially that there is the paradigm shift of their roles and characteristics with the additional changes because of the pandemic. Because of these roots, Constructivist Learning Theory will be a good approach to provide quality education. There will be less interactions between teacher to students and students to students so effort must be displaced to the curriculum especially in the Assessment.

This study is anchored on the Bruner's Constructivist Learning Theory where the role of the teacher, language and instruction are being greatly emphasized which are key points in the New Normal Education because of the adapted modalities. Readiness, Spiral organization, and Going beyond the information given are his principles in his Constructivist Learning.

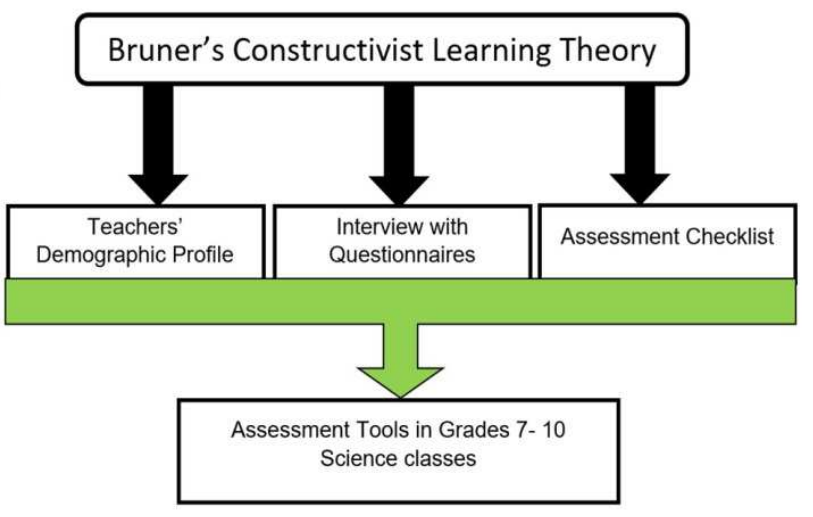

Figure 1. Conceptual Framework of the Study.

\subsection{Statement of the Problem}

This study attempted to identify how Science educators teach in the "New Normal" and to confirm that assessments are used to enable student's learning. It also shows the science educators' views about assessments, the factors in choosing and designing their assessments. Specifically, this answers the following objectives:

1. Identify how did they conduct assessments in the New Normal classes;

2. Determine the assessment tools and the principles used by the Science educators in their respective classes; and;

3. Recognize the challenges that they encounter in conducting the assessments to the learners.

\section{Review of Related Literature}

\subsection{Quality Education}

Amidst the challenges and difficulties brought by the COVID-19 in the Education sector, the Philippines' DepEd Secretary stressed that through the Basic Education Learning Continuity Plan, quality education will be provided [4].
Regardless of the available learning modalities, education sector must focus to instruction, participation, reinforcement, and feedback [5]. Also, quality education intends that through varied activities, learners can learn in the process and create their own knowledge actively, individually, and interpersonally [6].

\subsection{Distance Learning}

Because Face to Face learning is discouraged to follow protocols, Distance learning is the highlight of the "New Normal" Education. This requires great level of interaction between teacher and student in which teacher identifies and caters the students' diverse needs and address the problems faced by the students in the learning process [4]. Teachers in this pandemic must be sensitive and considerate to every student who chose either online, offline or blended learning. There are many opportunities given to students in these modalities but there are problems prevailing which are the communication between teacher-student and student-student and the splitting of student's attention [4]. With these, it is important that we, curriculum stakeholders, must exert great effort to our respective responsibilities because "If we fail to change our pedagogy, curriculum, and assessment strategies, we fail our students and jeopardize our own futures [7]."

\subsection{Assessment}

In the teaching-learning process, assessment is an integral factor because it can assess and check the students' acquired knowledge and skill [8]. Furthermore, assessment is an essential process that influences students' knowledge, skills, attitudes, and beliefs more than teaching [9] and it plays an important role in the implementation of the curriculum and identification of the students' performance and development and the resources or materials to be modified [4].

"Assessment is actually a set of strategies for discovering what students know or can do and it involves a number of activities designed to determine students' achievement" and these strategies are support to the students' attainment of their learning tasks and can be defined as "aspects of evaluation [6]." For instance, self-evaluation helps students to have motivation and responsibility for their performance [10]. Improvements in learners' performances are achieved through supportive feedback from various assessment tasks [11].

Assessment is composed of methods and techniques that serve as tool to show data about the different aspects of students especially about learning [8]. It also reveals the students' strengths and weaknesses which helps teachers in catering the needs of the students through providing quality reinforcement and feedback [8]. In addition, it pertains to the tasks attained by the students to check their performance and achievement [11].

Assessment could mean everything for the teachinglearning process in this New Normal to make sense. Students must be an active participant and the teacher must provide learning activities that can show the stored knowledge of 
students that will become a new knowledge after modifications [12]. Way back before and most especially in this time, "the challenge is to find ways to assess a range of outcomes that cannot be tested by measuring performance, as pen-and-paper tests form one small measure of what learners actually experience in the classroom [13]."

\subsection{Student Engagement}

Therefore, teachers need to create diverse assessment tools that will engage students in a HOTS-based learning process [9]. If students are engaged in the learning process and materials, they will enhance their different abilities and will have lifelong learning [7]. Only with awareness, will instructors learn the value of assessment, its effect on learning, and be capable of making changes [11].

Assessment tools include classic ways of testing and evaluating students using Paper-and-Pen Tests in an authentic way such as performance-based assessment. These tools will give the learners the opportunity to reflect on their own performance objectively [5]. With this, there will be improvement in their different life skills especially in making decision and solving problem [8].

\section{Research Design and Instruments}

This study is a descriptive research design using a qualitative method in which data is obtained via google form about the teaching and assessments Science educators used in the New Normal Education. The instruments used in this study include questionnaires and checklists that are provided to the respondents. The items in the research instruments are adapted, some are modified to be aligned with the objectives of the study, from the research studies of Arrieta, Gilbert \& Dancel, Jenalyn \& Agbisit, Mark Jayson. (2020) entitled "Teaching Science in The New Normal: Understanding The Experiences of Junior High School Science Teachers"'[16] and of Ogena, E. B., Yeban, F. I., Balagtas, M. U., Bedural, Z. L., Benoza, B. E. \& Atienza, B. S. P entitled "Education Imperative for the New Normal: Planning for Flexible Learning [17]." The sample of this study consisted of Science Educators in both private and public academic institutions handling Science classes from Grades 7 to 10 across different areas of Cebu which include City of Talisay, Municipality of Minglanilla, and City of Naga in the Province of Cebu.

\section{Presentation, Analysis, and Interpretation of Data}

Because of SARS-CoV-2, the government disallowed Face-to-Face Learning to follow mandated health protocols and mitigate the active cases of COVID-19 but emphasized the key role of Distance Learning also known as Remote Learning in New Normal Education. With the change in modality, there are also significant changes in the resources, instruction, and assessments used by the Science educators.
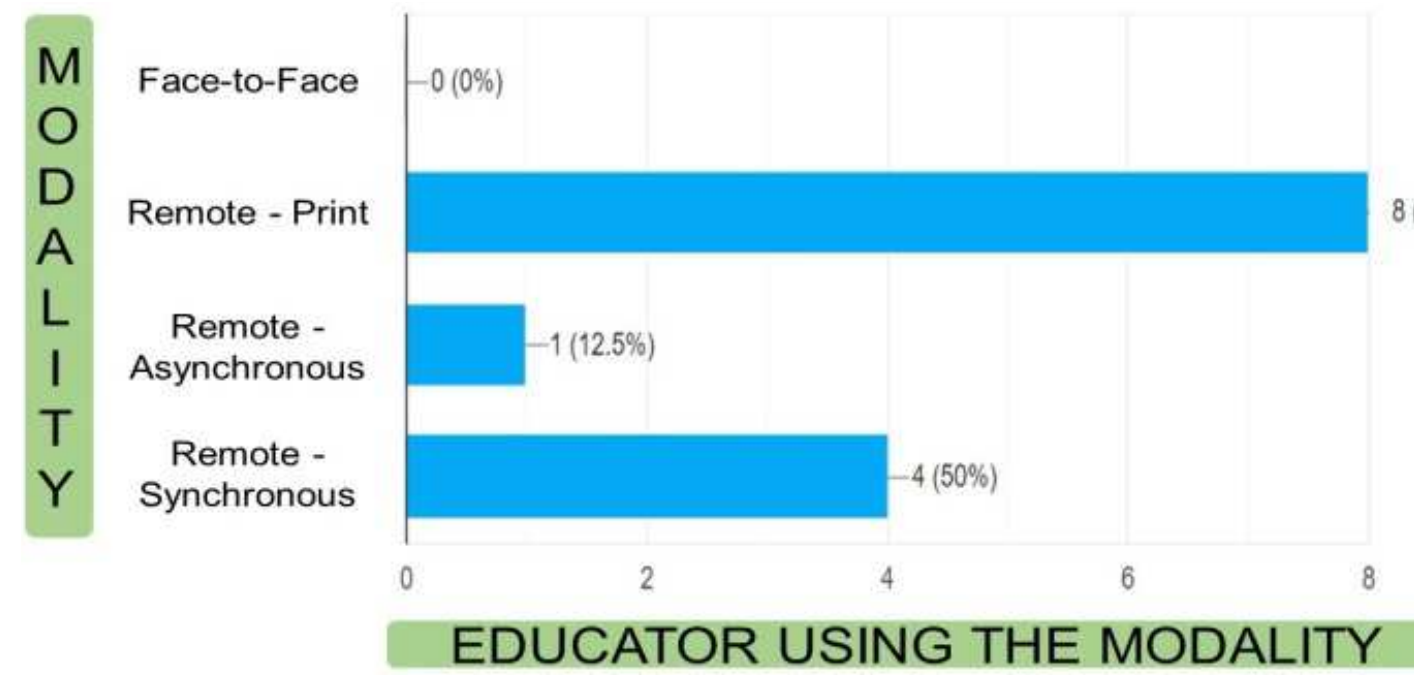

Figure 2. Educators with their Preferred Modalities.

In the study, there are four identified modalities of learning options to choose from and these are (1) Face-to-Face (F2F) Learning which refers to the traditional mode of conducting classes in the classroom, (2) Remote - Print Learning which refers to Modular Distance Learning (MDL), (3) Remote Online (Asynchronous) which uses digital materials for instruction purposes and (4) Remote - Online (Synchronous) which optimizing internet connectivity and online tools to deliver instruction. Out from these modalities, based on the data in Figure 2, respondents-educators teaching in both private and public academic institutions didn't conduct their classes face to face to follow government protocols and mitigate cases of COVID-19 and the most preferred modality is Modular Distance Learning which is both convenient for both teachers and students where the teaching-learning process exists through the provided self-learning kits or learning materials. In addition, Figure 2 shows that RemoteOnline Learning, Synchronous and Asynchronous, are not well-used because of lack of resources especially on the side of the learners. Despite these changes in modalities, science 
educators are still eager to provide quality education to the learners. Science educators identified the things they did in order to be prepared in the "New Normal " classes and these are participation in a series of online seminars and training, adaptation to technological tools/gadgets, and modification of learning competencies.

Science educators prepared paper-based and online assessments to cater diverse learners with different resources. There was a review of the curriculum and the most essential learning competencies. They identified what assessment would need synchronous administration to provide a specific schedule and create a paper format assessment that congruent to online format for those learners with poor or no connection. They made sure that there is student engagement and feedback in whatever format to ensure an effective teaching-learning process in the "New Normal" classes. Despite limited communication, science educators see to it that learners learn a lot by providing different assessment tools before, during, and after instructions. The assessment tools used before instruction include Standardized and Diagnostic Tests, used during instruction include Quizzes, Exercises, and Rubrics for Performance Tasks, and assessment tools used after the instruction include Quarterly Tests, Achievement Tests, Rubrics for Culminating Performance Tasks, and Rubrics for Portfolio Assessment. These assessment tools are crafted based on the guiding principles such as Purpose-driven, Practical, Fair/Inclusive, Valid, Holistic, Authentic, Balance, Reliable, Continuous, and Ethical which means these are good assessments because "a good assessment is defined as reliable, valid, and practicable and that it should have educational value [14]."

As a result of changes in conducting assessment, science educators experience challenges. In paper-based format, the only challenge is the credibility of the students' answers but in the online format, the challenges are the credibility as well as the unstable internet connection during assessment. In terms of credibility, there is a possibility that learners copy and paste their answers through different resources and a possibility that someone will answer it for them. To solve this, science educators must craft subjective, authentic assessments and provide a specific time for synchronous meetings. In addition, Science curriculum includes laboratory experiments which creates another challenge because learners at home may have a little to no availability of needed materials. To solve this, experiments procedures and materials must be designed according to home settings with less supervision to elders so that learners can perform the experiments easily.

\section{Summary of Findings, Presentation, Conclusion, and Recommendations}

In this study, it found out that as a result of following mandated government protocols in mitigating the cases of COVID-19, both private and public academic institutions exhibit dominantly the flexible learning modality which is Modular Distance Learning in their New Normal classes.
Science educators have less communication and supervision with their students so they prepared themselves a lot by attending a series of webinars and training, adapting to technological tools/gadgets and modifying learning competencies that are most essential to learn. Most of their preparation and effort go in designing a good self-learning kit or module and since this is their main line of communication to their students, it must contain assessment tools that will enable learners to learn effectively in home settings with less to no supervision. If teachers provide support to their students in the learning process then, students will have quality experiences which will greatly affect their sense of competence regardless of the types of the students [15]. To provide more support to students aside from a good self-learning kit, teachers integrate learning management system, social media apps, and educational websites in their classes. Despite this preparation and effort, science educators still confronted challenges in terms of the credibility of the students' answers, availability of materials needed in experiments at home, and unstable internet connection during scheduled meetings for assessment and feedback. To solve these, science educators must craft assessment tools with the guidelines such as Purpose-driven, Practical, Fair/Inclusive, Valid, Holistic, Authentic, Balance, Reliable, Continuous, and Ethical. In Science curriculum, relationship of concepts and ideas to personal encounters will enrich the students' interest and engagement [15]. If assessment tools stimulate interest and engagement, then these tools will serve as catalysts for students' learning in the New Normal. Therefore, it is highly suggested that curriculum stakeholders, especially educators must conduct seminars-workshops in crafting appropriate assessment tools and applying strategies in teaching and conducting assessments in different learning modalities that will provide quality education to diverse learners with different resources.

\section{References}

[1] The 2030 Sustainable Development Goals and the Pursuit of Quality Education for All: A Statement of Support from Education International and ASCD (2015). Retrieved from: http://www.ascd.org/ASCD/pdf/siteASCD/policy/ASCD-EIQuality-Education-Statement.pdf

[2] Hein, G. (1991). Constructivist learning theory. Retrieved from http://beta.edtechpolicy.org/AAASGW/Session2/const_inquir y_paper.pdf

[3] Conrad, Dianne \& Openo, Jason. (2018). Assessment Strategies for Online Learning: Engagement and Authenticity. 10.15215/aupress/9781771992329.01.

[4] Ancheta, Ruel \& Ancheta, Helen. (2020). THE NEW NORMAL IN EDUCATION: A CHALLENGE TO THE PRIVATE BASIC EDUCATION INSTITUTIONS IN THE PHILIPPINES? INTERNATIONAL JOURNAL OF EDUCATIONAL MANAGEMENT AND DEVELOPMENT STUDIES Volume 1, Issue 1 - September 2020. 
[5] Pekbay, C. and Koray, Ö. (2020). Alternative Assessment Tools Based on a Feedback Process: Perceptions of PreService Science Teachers. Malaysian Online Journal of Educational Sciences, v 8 n 1 p 50-63.

[6] Berry, R. (2010). Teachers' orientations towards selecting assessment strategies. Institute of Education New Horizons in Education, Vol. 58, No. 1.

[7] Parsons, J., \& Taylor, L. (2011). Improving Student Engagement. Current Issues in Education, 14 (1). Retrieved from

https://cie.asu.edu/ojs/index.php/cieatasu/article/view/745

[8] Tosuncuoglu, Irfan. (2018). Importance of Assessment in ELT. Journal of Education and Training Studies. 6. 163. 10.11114/jets.v6i9.3443.

[9] Ichsan, I. Z et al. (2020) Designing an Innovative Assessment of HOTS in the Science Learning for the 21st Century. Jurnal Penelitian dan Pembelajaran IPA JPPI Vol. 6, No. 2, 2020, p. 211-224.

[10] Said, M. M. T, Aravind, V. R., Ferdinand-James, D. \& Umachandran, K. (2019). Dissecting assessment: A paradigm shift towards technology-enhanced assessments. World Journal on Educational Technology: Current Issues.

[11] Rawlusyk, P. E. (2018). Assessment in Higher Education and Student Learning. Journal of Instructional Pedagogies, Vol. 21.
[12] Bada, \& Olusegun, S. (2015). Constructivism Learning Theory: A Paradigm for Teaching and Learning. IOSR Journal of Research \& Method in Education Volume 5, Issue 6 Ver. I (Nov. - Dec. 2015), PP 66-70.

[13] Stears, M. and Gopal, N. (2010). Exploring alternative assessment strategies in science classrooms. South African Journal of Education, Vol. 30, No. 4.

[14] Lucila Giammatteo, Adolfo V. Obaya. (2018). Assessing Chemistry Laboratory Skills Through a Competency based Approach in High School Chemistry Course. Science Education International 29 (2), 103-109.

[15] Cláudia Faria, Sofia Freire, Cecília Galvão, Pedro Reis and Mónica Baptista (2012). Students at risk of dropping out: how to promote their engagement with school science? Science Education International Vol. 23, No. 1, March 2012, 20-39.

[16] Arrieta, Gilbert \& Dancel, Jenalyn \& Agbisit, Mark Jayson. (2020). Teaching Science in The New Normal: Understanding The Experiences of Junior High School Science Teachers. JURNAL PENDIDIKAN MIPA. 146-162. 10.23960/jpmipa/v21i2. pp 146-162.;

[17] Ogena, E. B., Yeban, F. I., Balagtas, M. U., Bedural, Z. L., Benoza, B. E. \& Atienza, B. S. P. (June 2020). Education Imperative for the New Normal: Planning for Flexible Learning. E-Toolkit for the Philippine Association of Private Schools, Colleges and Universities, Inc. Webinar Series (June 2020) https://peac.org.ph/wpcontent/uploads/2020/06/Final.PAPSCUToolkit28June2020.pdf 